\title{
Seed Yield and Water Productivity of Irrigated Winter Canola (Brassica napus L.) under Semiarid Climate and High Elevation
}

\author{
Koffi Djaman ${ }^{1, * \mathbb{B}}$, Michael O'Neill ${ }^{1}$, Curtis Owen ${ }^{1}$, Daniel Smeal ${ }^{1}$, Margaret West ${ }^{1}$, \\ Dallen Begay ${ }^{1}$, Sangamesh V. Angadi ${ }^{2}$, Komlan Koudahe ${ }^{3}{ }^{(D)}$, Samuel Allen ${ }^{1}$ and \\ Kevin Lombard ${ }^{1}$ \\ 1 Department of Plant and Environmental Sciences, New Mexico State University, Agricultural Science Center \\ at Farmington, P.O. Box 1018, Farmington, NM 87499, USA; moneill@nmsu.edu (M.O.); \\ cowen@nmsu.edu (C.O.); dsmeal@nmsu.edu (D.S.); Mwest@nmsu.edu (M.W.); dallenb@nmsu.edu (D.B.); \\ samallen@nmsu.edu (S.A.); klombard@nmsu.edu (K.L.) \\ 2 Department of Plant and Environmental Sciences, New Mexico State University, Agricultural Science Center \\ at Clovis, Clovis, NM 88101, USA; angadis@ad.nmsu.edu \\ 3 ADA Consulting Africa, 07 BP 14284 Lomé, Togo; komlankoudahe@gmail.com \\ * Correspondence: kdjaman@nmsu.edu; Tel.: +1-505-960-7757
}

Received: 17 April 2018; Accepted: 5 June 2018; Published: 6 June 2018

\begin{abstract}
Canola is a cash crop produced for its highly-valued seed, and as a protein source for animal feed. While winter canola is produced mainly in the high plains, it is expanding to new environments, and is greatly incorporated into crop systems with advantages in terms of increasing crop yield and improving soil health. The objectives of this study were to evaluate eight winter canola genotypes for seed yield, and to determine their water productivity under semiarid climates and high elevations in the Four Corners region at Farmington, New Mexico. A field experiment was conducted at the New Mexico State Agricultural Science Center at Farmington for five growing seasons. Eight genotypes of winter canola (Baldur, Flash, Safran, Sitro, Virginia, Visby, Wichita, and Sumner) were arranged into the randomized complete block design. The field was fully irrigated with a center pivot irrigation system. Results showed that winter canola seed yield was dependent on genotype, varying from 2393 to $5717 \mathrm{~kg} / \mathrm{ha}$. The highest yield was achieved by Sitro, and the lowest yield by Sumner. There was inter-annual variation in canola nitrogen-use efficiency (NUE), irrigation water-use efficiency (IWUE), and crop water-use efficiency (CWUE). NUE varied from 12.9 to $50.4 \mathrm{~kg}$ seed $/ \mathrm{kg} \mathrm{N}$, with the highest NUE achieved by Sitro, and the lowest by Sumner. IWUE varied from 0.34 to $0.80 \mathrm{~kg} / \mathrm{m}^{3}$, and canola CWUE from 0.28 to $0.69 \mathrm{~kg} / \mathrm{m}^{3}$. The highest water productivity was achieved by Sitro. The results of this study showed full assessment of canola production under the semiarid climate in the Four Corners region, and could improve crop productivity and profitability.
\end{abstract}

Keywords: winter canola; seed yield; irrigation; water productivity; semiarid climate; high elevation

\section{Introduction}

Canola (Brassica napus L.) is the second largest oil seed after soybean worldwide, producing high-protein meal used for animal feed during processing [1,2]. While canola was traditionally produced for birds and industry, it became more economically attractive, and the new varieties could be used for animal grazing, since the seed cake is an important source of protein in livestock feeding [3-5]. Its integration into the crop system in rotation with wheat [6] and Barley [7] significantly improved the yield of all the crops, eliminated soil-born cereal pathogens and root maggot damage, and reduced the impact of pathogen diseases on the yield of the cereals [8,9]. In 2017, United States 
was the 7th largest canola oil producer (1,013,000 tons), led by Canada (18,362,000 tons), and followed by China, India, Australia, Ukraine, and Russia [10]. In North America, Canada is the largest canola producer, with $90 \%$ of the production [4] and increasing harvested yields since 1990 [11]. US canola production in 2017 was 14,143,010.097 tons, with a national average yield of $1746 \mathrm{~kg} / \mathrm{ha}$; the leading States, in order, were North Dakota, Oklahoma, Montana, Washington, Minnesota, Kansas, Idaho, and Oregon [12]. Canola yield depends on numerous factors, including genotypes [13-16], seeding density [17,18], climate [9,19-21], soil type [20], watering regime [22-25], fertilizer rate and application timing [26-32], seeding rate and depth, crop rotation, tillage practices, and planting date [33-35].

Winter canola is produced in the US mostly in North Dakota (90\% of the production), Idaho, and Minnesota [36]. However, winter canola production is expanding into southern US, and has the potential for dual-purpose production for forage and seed production [37,38]. Winter canola production is adapted to the Southern Great Plains $[39,40]$, and is expanding into the south western US [13,14,37,38]. Begna et al. [38] reported winter canola seed yield ranges of 930-4360 kg/ha for three winter canola cultivars (DKW44-10, Griffin, and Safran). Neely et al. [41] reported winter canola seed yield 387 and $2931 \mathrm{~kg} / \mathrm{ha}$ for different genotypes under different planting dates across the State of Texas. While winter canola has advantages for improving global crop system production and soil health, plant lodging can negatively affect seed yield, oil quality, and harvest ability, due to inappropriate planting dates and fertilizer management [10,42-44]. In the southern United States, winter canola may suffer the early fall and late winter freezes if the optimum planting date is not respected, similar to winter wheat and maize in the Four Corners region [45]. Trostle et al. [46] reported winter canola killed by winter freeze injury at Etter, Texas. Seedling survival is affected by low temperatures, and spring frosts and canola seed yield is affected [3,47].

While extensive research activities had been conducted in the northern US, mostly in the Northern Great Plains, very limited data and information exist on winter canola establishment across the southwestern US, and at high elevations. The objectives of this study were to evaluate grain yield of some winter canola genotypes, and to determine their water productivity under semiarid climates and high elevations at Farmington, New Mexico.

\section{Materials and Methods}

\subsection{Station Area}

A long-term experiment was conducted at the New Mexico State University (NMSU) Agricultural Science Center at Farmington (Latitude 36.69' North, Longitude 108.31' West, elevation $1720 \mathrm{~m}$ ) for the period of 2008-2013. Minimum temperature (Tmin), maximum temperature (Tmax), mean relative humidity (RHmean), wind speed $\left(\mathrm{U}_{2}\right)$, and solar radiation (Rs) were collected on a daily basis from an automated weather station installed at the site by the New Mexico Climate Center. Annual average weather conditions during the winter canola growing period (1st September to 31st July) are presented in Figures 1 and 2.

\subsection{Experimental Design and Crop Management}

This study consisted of evaluating winter canola genotypes for seed yield under the semiarid climate and high elevation. Eight winter canola genotypes varieties (Baldur, Flash, Safran, Sitro, Sumner, Virginia, Visby, and Wichita,) were arranged in a completely randomized block design with four replications. These winter canola genotypes were continuously used as checks in a large national winter canola variety trial, coordinated by Kansas State University. The winter canola genotype was studied; the fixe effect on seed yield and other effects (management practice, soil type, etc.) were considered random, as the field was managed evenly among genotypes. The planting rate was $5.6 \mathrm{~kg}$ of seed per hectare. The planting date, harvesting date, applied fertilizer rate, seasonal precipitation, and seasonal applied irrigation are summarized in Table 1. The field was kept weed free by herbicide application or hand weeding, as needed. Insecticide was also applied when any 
significant insect damage was noticed. The field was fully irrigated by a center pivot irrigation system to avoid drought stress.

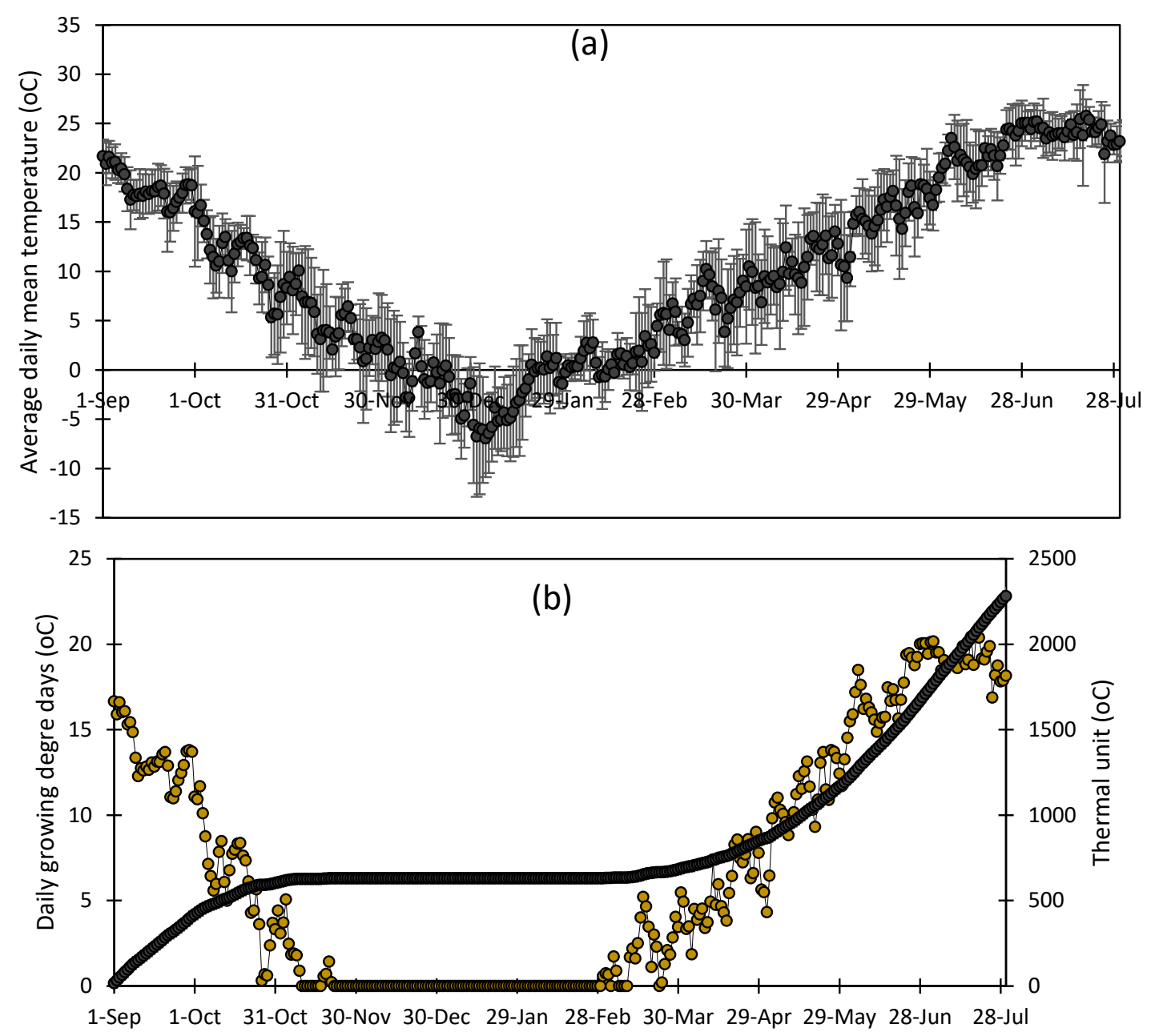

Figure 1. Trends in the (a) Daily average temperature and (b) Growing degree day and thermal unit for the period of 1st September to 31st July.

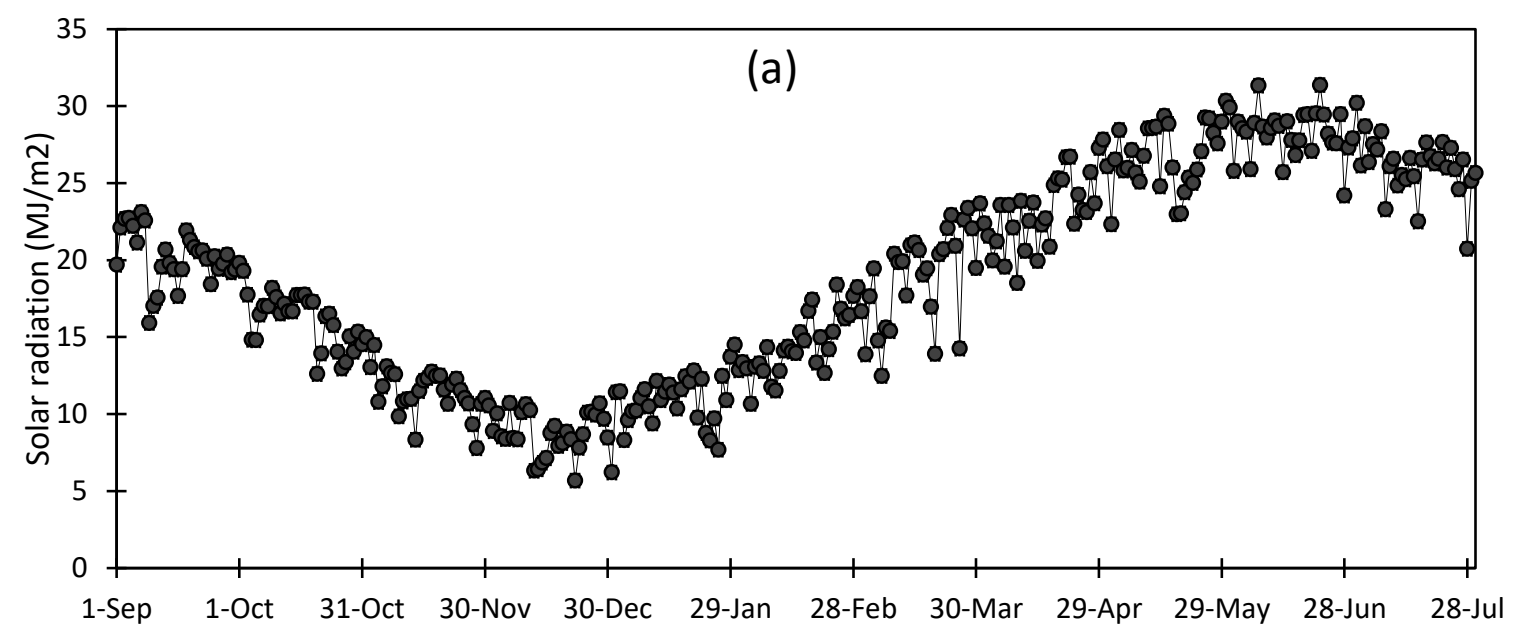

Figure 2. Cont. 

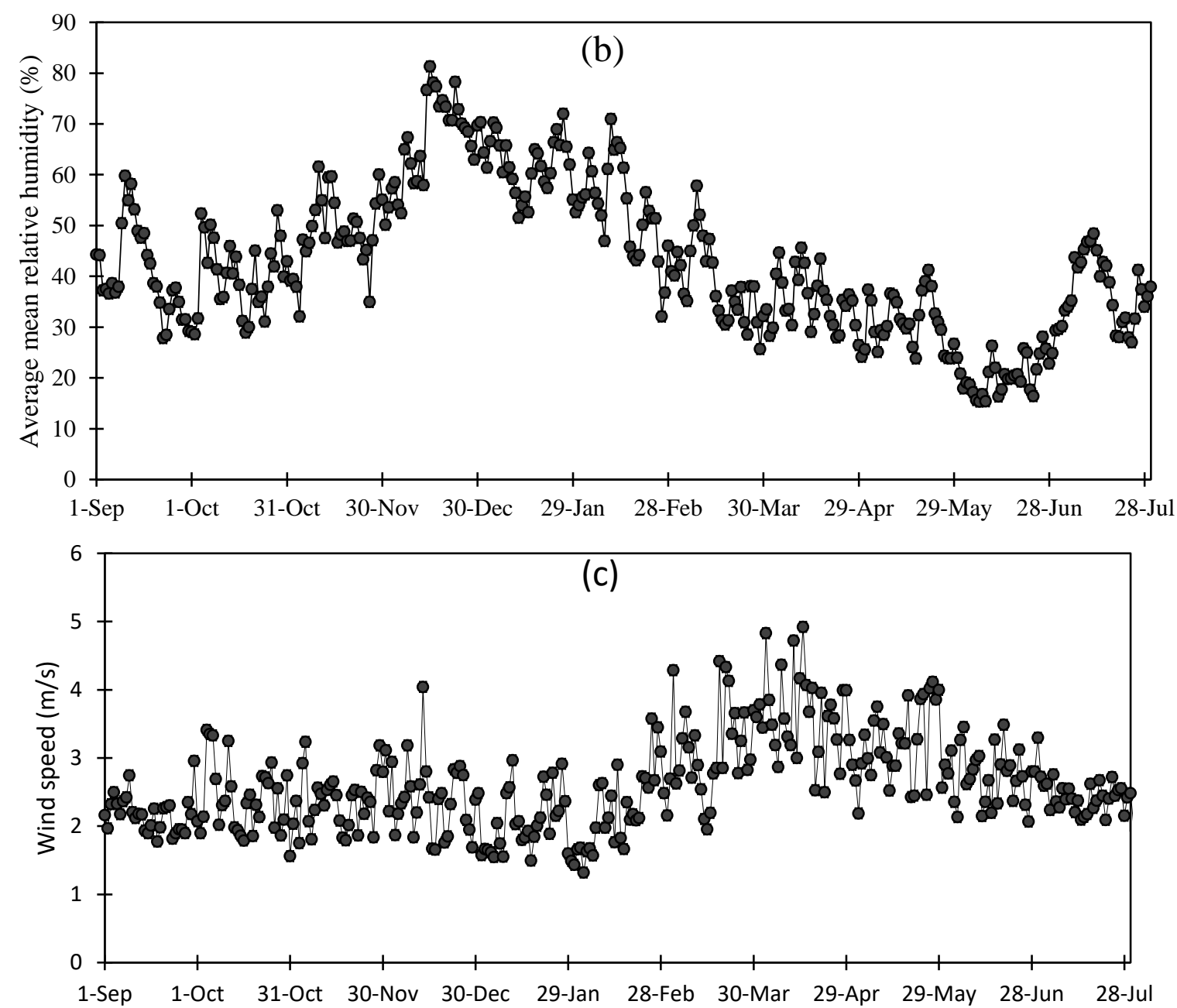

Figure 2. Trends in the average (a) Daily solar radiation; (b) Relative humidity; (c) Wind speed for the period of 1st September to 31st July.

Table 1. Canola planting and harvesting date, and the applied fertilizer rate, precipitation and irrigation applied during the 2008-2013 period.

\begin{tabular}{|c|c|c|c|c|c|c|c|c|}
\hline \multirow[t]{2}{*}{ Year } & \multirow{2}{*}{$\begin{array}{l}\text { Planting } \\
\text { Date }\end{array}$} & \multirow{2}{*}{$\begin{array}{l}\text { Harvesting } \\
\text { Date }\end{array}$} & \multirow[t]{2}{*}{ Soil Type } & \multirow[t]{2}{*}{ Previous Crop } & \multirow{2}{*}{$\begin{array}{c}\text { N-P2O5-K2O- } \\
\text { ZnSO4 } \\
(\mathrm{kg} / \mathrm{ha})\end{array}$} & \multirow{2}{*}{$\begin{array}{c}\text { Precipitation } \\
(\mathrm{mm})\end{array}$} & \multirow{2}{*}{$\begin{array}{c}\text { Irrigation } \\
(\mathrm{mm})\end{array}$} & \multirow{2}{*}{$\begin{array}{c}\begin{array}{r}\text { Water } \\
\text { Supply }\end{array} \\
(\mathrm{mm})\end{array}$} \\
\hline & & & & & & & & \\
\hline 2008 & 5-Sep & & & & & & & \\
\hline 2009 & 3-Sep & 29-Jul & $\begin{array}{l}\text { Doak } \\
\text { sandy } \\
\text { loam }\end{array}$ & Potatoes-Fallow & $168-58-67-0$ & 122 & 711 & 833 \\
\hline 2010 & 7-Sep & 29-Jul & $\begin{array}{l}\text { Doak } \\
\text { sandy } \\
\text { loam }\end{array}$ & Corn-Fallow & $129-58-67-0$ & 130 & 660 & 790 \\
\hline 2011 & 8-Sep & 21-Jul & $\begin{array}{l}\text { Doak } \\
\text { sandy } \\
\text { loam }\end{array}$ & Oats-Fallow & $185-0-0-0$ & 142 & 704 & 846 \\
\hline 2012 & 6-Sep & 16-Jul & $\begin{array}{l}\text { Doak } \\
\text { sandy } \\
\text { loam }\end{array}$ & Potatoes-Fallow & $112-58-67-16$ & 115 & 737 & 852 \\
\hline 2013 & & 18-Jul & $\begin{array}{l}\text { Doak } \\
\text { sandy } \\
\text { loam }\end{array}$ & Potatoes-Fallow & $230-117-135-40$ & 89 & 615 & 703 \\
\hline
\end{tabular}




\subsection{Thermal Unit (TU)}

The Thermal Unit (TU) is the accumulation of the growing degree days (GDD), i.e., cumulative temperature that contributes to plant growth during the growing season, and is expressed as follows:

$$
\mathrm{TU}=\sum_{i=1}^{n} \frac{\mathrm{Tmax}+\mathrm{Tmin}}{2}-\text { Tbase }
$$

where Tmax $=$ maximum air temperature, Tmin $=$ minimum air temperature, Tbase $=$ base temperature threshold for winter canola $\left(5^{\circ} \mathrm{C}\right)$, and $n=$ number of days. The base temperature for calculating growing degree days is the minimum threshold temperature at which plant growth starts. Thermal time requirements for canola were recorded in GDD using $5{ }^{\circ} \mathrm{C}$ as the base temperature [48]. The maximum and minimum temperature thresholds of $30^{\circ} \mathrm{C}$ and $5{ }^{\circ} \mathrm{C}$ respectively were used. All temperature values exceeding the threshold were reduced to $30^{\circ} \mathrm{C}$, and values below $5{ }^{\circ} \mathrm{C}$ were taken as $0{ }^{\circ} \mathrm{C}$, because no growth occurs above or below the threshold (base) temperature values. If the average daily temperature was below the base temperature, the TU value was assumed to be zero.

\subsection{Crop Water Use Efficiency}

Seasonal irrigation water use efficiency (IWUE) and crop water use efficiency related to total water supply (CWUE) were estimated by the following equations:

$$
\begin{array}{r}
\text { IWUE }=\frac{\text { Yield }}{\text { Seasonal irrigation amount }} \\
\text { CWUE }=\frac{\text { Yield }}{\text { Seasonal water supply }}
\end{array}
$$

where IWUE and CWUE and are in $\mathrm{kg} / \mathrm{m}^{3}$, yield is in $\mathrm{kg} / \mathrm{ha}$, the seasonal irrigation amount in $\mathrm{mm}$.

\subsection{Statistical Analysis}

The effects of canola varieties and the seasons, as well as their potential interaction on canola yield, were analyzed using an analysis of variance (ANOVA) in PROC MIXED in SAS (2001) (SAS Institute, Cary, NC, USA). Separation of means was determined with the LSMEANS statement at the $5 \%$ significance level, to identify any potential significant differences between eight winter canola genotypes' seed yields.

\section{Results and Discussion}

\subsection{Climatic Conditions during the Winter Canola Growth Period}

Weather conditions at the experimental site during the winter canola growing season was reported for the period of 1st September to 31st July (Figure 1). There was only a slight difference in wind speed, air temperature, relative humidity, and solar radiation among growing seasons. Seasonal average wind speed varied from 2.44 to $2.80 \mathrm{~m} / \mathrm{s}$; the strongest wind occurred during the 2008-2009 season. Average season Tmax varied from 17.18 to $19.13{ }^{\circ} \mathrm{C}$, the Tmin varied from 1.98 to $3.33{ }^{\circ} \mathrm{C}$, and Tmean varied from 9.3 to $10.7^{\circ} \mathrm{C}$. The highest solar radiation occurred during the 2012-2013 season, with an average seasonal daily Rs value of $19.12 \mathrm{MJ} / \mathrm{m}^{2}$. Average daily mean temperature decreased from 21.6 on (1st September) to to $-7.0^{\circ} \mathrm{C}$ on 4 January, and increased thereafter to $25.4{ }^{\circ} \mathrm{C}$. Air temperature remained below freezing point from 8 January to 15 February (Figure 1a). Thermal time requirements for canola were recorded in GDD using $5{ }^{\circ} \mathrm{C}$ as the base temperature [48], and decreased from $16.61{ }^{\circ} \mathrm{C}$ to $0{ }^{\circ} \mathrm{C}$ from 1st-September 10 November, remaining basically null until March 5, and increasing thereafter to $19.8^{\circ} \mathrm{C}$ (Figure 1b). Winter canola was in the dormancy period without physiological activity and growth from early November to early March. The cumulative GDD 
(thermal unit) increased from September to early November, remaining constant during the winter canola dormancy period and increasing thereafter when the average air temperature was above the winter canola base temperature $\left(5^{\circ} \mathrm{C}\right)$. Average seasonal total thermal units accumulated were $2283^{\circ} \mathrm{C}$ (Figure 1b). Daily average solar radiation showed the same trends as those of the daily air temperature, ranging from 5.7 to $31.4 \mathrm{MJ} / \mathrm{m}^{2}$, and averaging $18.68 \mathrm{MJ} / \mathrm{m}^{2}$ (Figure 2a). Average daily relative humidity varied from $15.4 \%$ to $81.3 \%$, increasing from September to mid-December and decreasing toward the end of the growing season (Figure $2 b$ ). Seasonal average relative humidity was $42.9 \%$, revealing the dryness of the local semiarid climate with very non-significant precipitation during the season, and considerable irrigation requirements during all the five growing seasons (Table 1). Seasonal wind speed averaged $2.6 \mathrm{~m} / \mathrm{s}$, and was the strongest in March and April, with daily variability during the rest of the season (Figure 2c).

\subsection{Winter Canola Seed Yield}

Canola seed yield varied from 2393 to $5717 \mathrm{~kg} / \mathrm{ha}$, and there was significant dependence of seed yield on canola variety (Figure 3). Canola variety Sitro showed a highest average seed yield of $4570 \mathrm{~kg} / \mathrm{ha}$, followed by Safran, with a seed yield of $4378 \mathrm{~kg} / \mathrm{ha}$; the lowest average yield, $2932 \mathrm{~kg} / \mathrm{ha}$, was obtained by the Sumner variety (Figure 4) (Table 2). Seed yield showed significant inter-annual variability $(p=0.001)$; the highest yields were obtained during the 2011-2012 season, while the lowest yields were obtained during the 2010-2011 season. In comparison to the seed yield of Sumner (lowest yielding variety), there were $24.2,42.4,49.3,55.8,29.5,41.8$, and $20.5 \%$ higher yields for the varieties Baldur, Flash, Safran, Sitro, Virginia, Visby, and Wichita, respectively. Therefore, Sitro and Safran should be the first choice when considering Canola production under the Farmington climatic, soil, and management conditions. The results of the present study aligned with Assefa et al. [35], who reported a canola seed average yield of $3400 \mathrm{~kg} / \mathrm{ha}$ for spring varieties, with a maximum yield of $6600 \mathrm{~kg} / \mathrm{ha}$, and seed average yield of $2500 \mathrm{~kg} / \mathrm{ha}$ with a maximum yield of $5400 \mathrm{~kg} / \mathrm{ha}$ for winter canola varieties. Pavlista et al. [20] reported a spring canola seed yield that varied among varieties (SW Patriot, Hyola 401 and Hyola 357 Magnum, SW Marksman) and regions across the US High Plains, ranging from 696 to $2326 \mathrm{~kg} / \mathrm{ha}$, with the highest yield recorded at Famington, NM. Hergert et al. [49] reported spring canola seed yields ranging from 440 to $3289 \mathrm{~kg} / \mathrm{ha}$ in western Nebraska, under full and limited irrigation settings. Assefa et al. [50] recorded a maximum yield range of 5000-7000 kg/ha. The seed yields reported in this study are higher than the average national seed yield of $2044 \mathrm{~kg} / \mathrm{ha}$ for the US and $2306 \mathrm{~kg} / \mathrm{ha}$ for Canada [1]. Assefa et al. [50] reported a winter canola seed yield varying from 0 to $4000 \mathrm{~kg} / \mathrm{ha}$ in Manhattan, KS, while yield potential reached $7000 \mathrm{~kg} / \mathrm{ha}$. However, slightly higher yields are obtained in this study, confirming the results of Assefa et al. [50], with higher yields in the southeast USA than in the Midwest. Different performance of the same varieties used in the present study was reported across several states in the eastern, midwest and northwest US in a national canola variety trial; the highest yields were the following: $4257 \mathrm{~kg} / \mathrm{ha}$, obtained by Sitro at Fruita, Co; $4894 \mathrm{~kg} / \mathrm{ha}$ by Sitro at Belleville IL; $4002 \mathrm{~kg} / \mathrm{ha}$ by Safran at Carbondale, IL; $1558 \mathrm{~kg} / \mathrm{ha}$ by Visby at Monmouth, IL, $2700 \mathrm{~kg} / \mathrm{ha}$ by Flash at Urbana, IL [51,52]. Sitro outperformed the other varieties, and Wichita was among the lowest-yielding cultivars used at different planting dates in Manhattan, KS [50]. The high yield achieved at the Farmington site in comparison to many part of the United States [12-16] might be due to higher radiation use efficiency at the study site leading to higher levels of photosynthesis, as reported by Yang et al. [17]. Winter canola generally performed best when seeded in early September in central Iowa [53]. Winter canola yield might increase with appropriate water supply, balanced nutrition, early planting in shallow depth, high seeding rate $\left(6 \mathrm{~kg} \mathrm{ha}^{-1}\right)$, and diverse rotation (canola every 3 or 4 year) and the good agricultural practices [35]. 


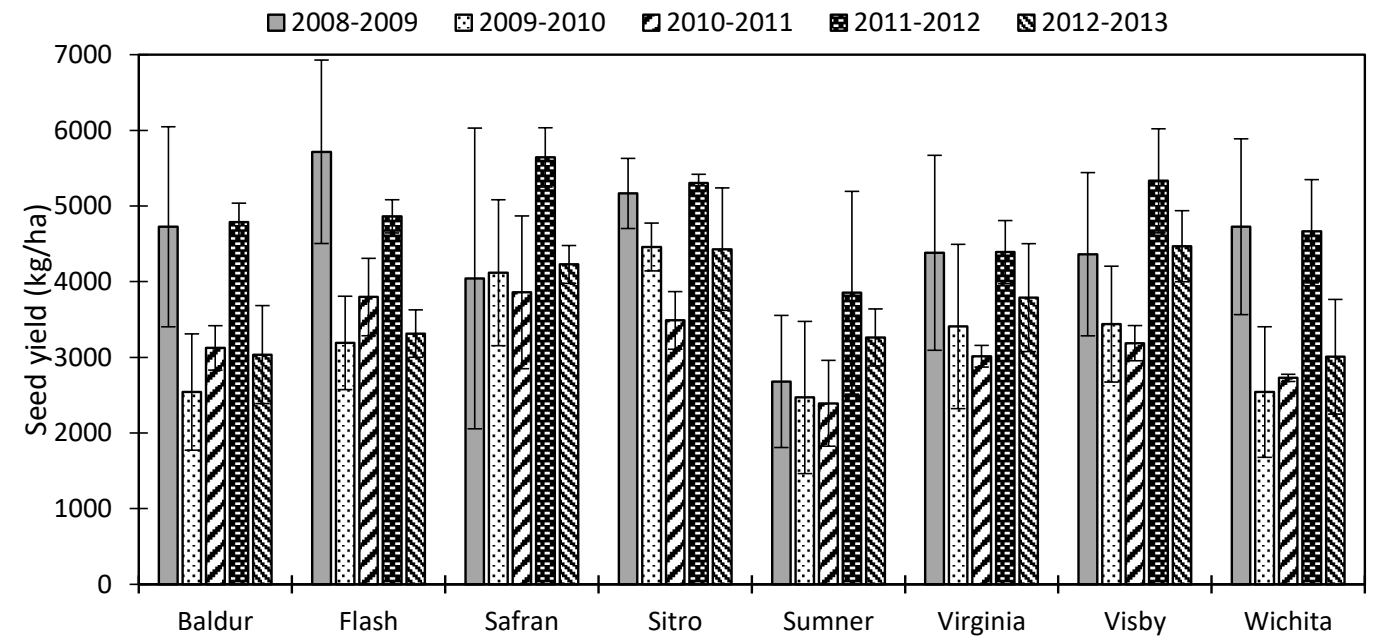

Figure 3. Average and standard deviation of winter canola seed yield for the 2008-2013 period.

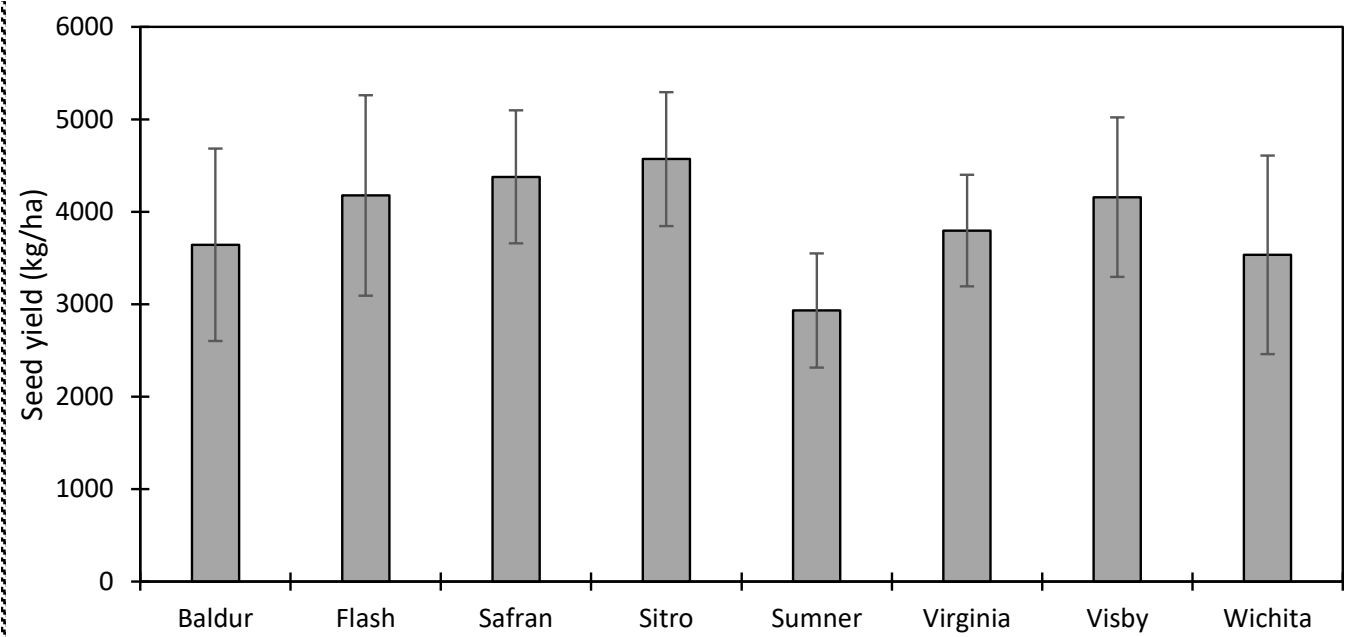

Figure 4. Average and standard deviation of winter canola seed yield for the 2008-2013 period.

Table 2. Canola seed yield, nitrogen use efficiency, irrigation and crop water use efficiencies.

\begin{tabular}{|c|c|c|c|c|c|c|c|c|c|}
\hline \multirow{2}{*}{ Parameters } & \multirow{2}{*}{ Growing Season } & \multicolumn{8}{|c|}{ Varieties } \\
\hline & & Baldur & Flash & Safran & Sitro & Sumner & Virginia & Visby & Wichita \\
\hline \multirow{5}{*}{ Seed yield (kg/ha) } & 2008-09 & 4726 & 5717 & 4043 & 5166 & 2681 & 4382 & 4363 & 4726 \\
\hline & 2009-10 & 2541 & 3191 & 4118 & 4459 & 2469 & 3408 & 3439 & 2541 \\
\hline & 2010-11 & 3125 & 3797 & 3859 & 3488 & 2393 & 3015 & 3188 & 2729 \\
\hline & 2011-12 & 4787 & 4863 & 5643 & 5305 & 3854 & 4390 & 5333 & 4666 \\
\hline & $2012-13$ & 3036 & 3314 & 4228 & 4430 & 3263 & 3790 & 4469 & 3008 \\
\hline \multirow{5}{*}{$\begin{array}{c}\text { Nitrogen use } \\
\text { efficiency }(\mathrm{kg} / \mathrm{kg})\end{array}$} & 2008-09 & 28.1 & 34.0 & 24.1 & 30.8 & 16.0 & 26.1 & 26.0 & 28.1 \\
\hline & 2009-10 & 19.7 & 24.7 & 31.9 & 34.6 & 19.1 & 26.4 & 26.7 & 19.7 \\
\hline & 2010-11 & 16.9 & 20.5 & 20.9 & 18.9 & 12.9 & 16.3 & 17.2 & 14.8 \\
\hline & 2011-12 & 42.7 & 43.4 & 50.4 & 47.4 & 34.4 & 39.2 & 47.6 & 41.7 \\
\hline & $2012-13$ & 13.2 & 14.4 & 18.4 & 19.3 & 14.2 & 16.5 & 19.4 & 13.1 \\
\hline \multirow{5}{*}{$\begin{array}{l}\text { Irrigation water } \\
\text { use efficiency } \\
\left(\mathrm{kg} / \mathrm{m}^{3}\right)\end{array}$} & 2008-09 & 0.66 & 0.80 & 0.57 & 0.73 & 0.38 & 0.62 & 0.61 & 0.66 \\
\hline & 2009-10 & 0.38 & 0.48 & 0.62 & 0.68 & 0.37 & 0.52 & 0.52 & 0.38 \\
\hline & 2010-11 & 0.44 & 0.54 & 0.55 & 0.50 & 0.34 & 0.43 & 0.45 & 0.39 \\
\hline & 2011-12 & 0.65 & 0.66 & 0.77 & 0.72 & 0.52 & 0.60 & 0.72 & 0.63 \\
\hline & $2012-13$ & 0.49 & 0.54 & 0.69 & 0.72 & 0.53 & 0.62 & 0.73 & 0.49 \\
\hline \multirow{5}{*}{$\begin{array}{l}\text { Crop water use } \\
\text { efficiency }\left(\mathrm{kg} / \mathrm{m}^{3}\right)\end{array}$} & 2008-09 & 0.57 & 0.69 & 0.49 & 0.62 & 0.32 & 0.53 & 0.52 & 0.57 \\
\hline & 2009-10 & 0.32 & 0.40 & 0.52 & 0.56 & 0.31 & 0.43 & 0.44 & 0.32 \\
\hline & 2010-11 & 0.37 & 0.45 & 0.46 & 0.41 & 0.28 & 0.36 & 0.38 & 0.32 \\
\hline & 2011-12 & 0.56 & 0.57 & 0.66 & 0.62 & 0.45 & 0.52 & 0.63 & 0.55 \\
\hline & $2012-13$ & 0.43 & 0.47 & 0.60 & 0.63 & 0.46 & 0.54 & 0.64 & 0.43 \\
\hline
\end{tabular}




\subsection{Winter Canola Nitrogen Use Efficiency}

Nitrogen use efficiency (NUE) of the winter canola, defined as the ratio of seed yield to the applied nitrogen, varied with the genotypes and growing seasons (Table 2). With all genotypes combined, there was poor correlation between seed yield and the applied nitrogen rate (Figure 5). Canola genotypes had different responses to nitrogen fertilizers (Figure 5). NUE varied from 12.9 to $50.4 \mathrm{~kg}$ seed $/ \mathrm{kg}$ $\mathrm{N}$, and the five season average NUE was within the range of 19.3 to $30.2 \mathrm{~kg}$ seed $/ \mathrm{kg} \mathrm{N}$ (Figure 6). The highest NUE was obtained by Sitro, and the lowest by Sumner. The highest NUE across all varieties was obtained during the 2011-2012 season, and the lowest during the 2012-2013 season. Canola plot rotation, seasonal climatic conditions, nutrient management, and other agricultural practices might explain NUE variation for the same variety throughout the study period. Canola NUE decreased with higher nitrogen rates [54,55]. Koocheki et al. [56] stated that NUE varied from 4.20 to $22.03 \mathrm{~kg}$ seed $/ \mathrm{kg}$ $\mathrm{N}$ at the research station of Ferdowsi University of Mashhad, Iran. Variation in NUE among genotypes might originate from differences in leaf area index and radiation use efficiency, and the stay green phenotype in canola, all of which affect timely nitrogen uptake efficiency during the reproductive phase of the plant [57]. Svecnjak and Rengel [58] attributed the differences in NUE among canola cultivars to differences in root to shoot ratio and harvest index. Nitrogen fertilizer application rate and timing should be considered under sandy soil conditions in the present experiment. Low fertigation rates should be applied on sandy soils to reduce deep percolation and eliminate nitrogen leaching beyond the crop root zone [59].

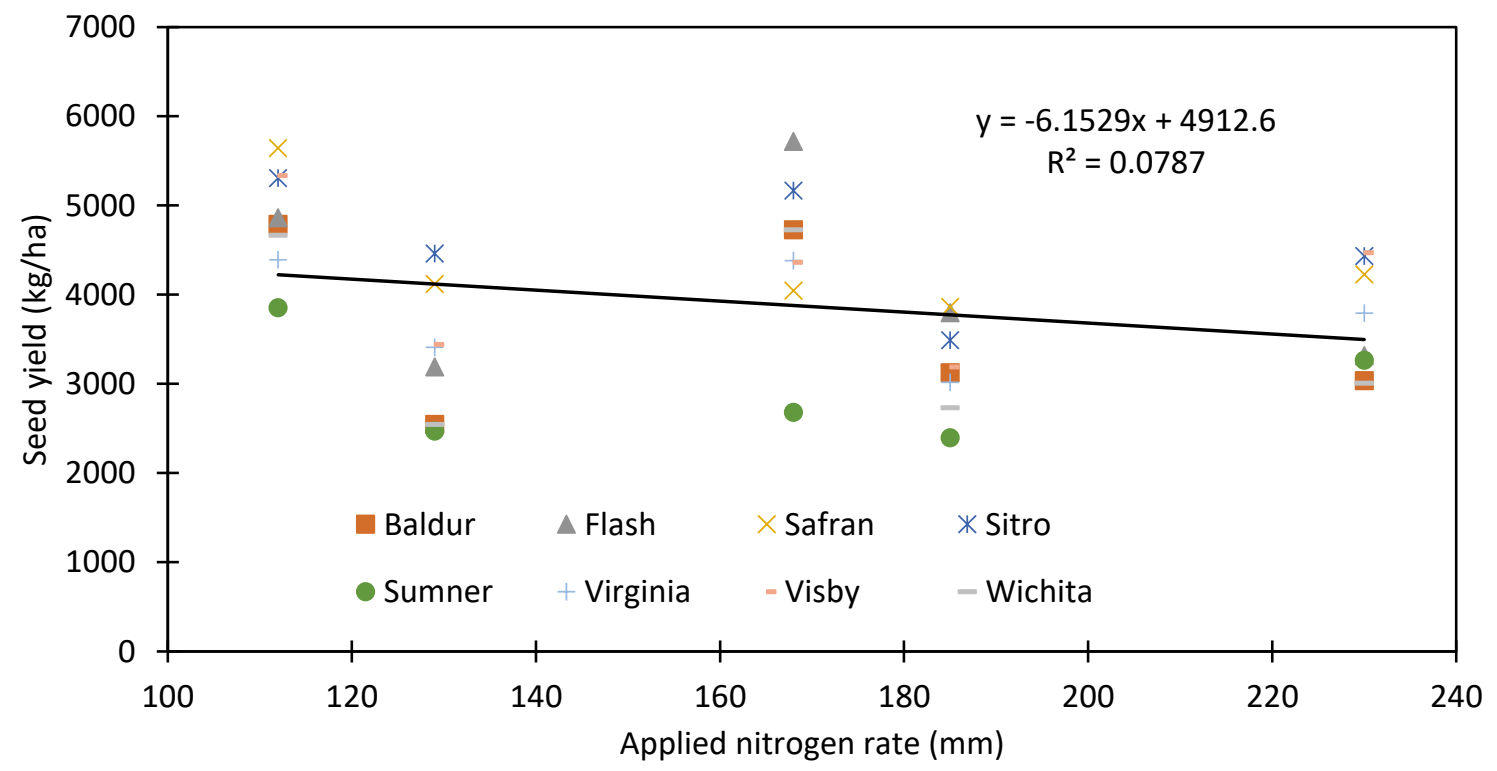

Figure 5. Relationship between winter canola seed yield and applied nitrogen amount.

\subsection{Winter Canola Irrigation Water and Crop Water Use Efficiency}

Winter canola IWUE varied from 0.34 to $0.80 \mathrm{~kg} / \mathrm{m}^{3}$, and was dependent on canola genotype (Table 2). Overall, there was poor correlation between winter canola seed yield and the seasonal irrigation amount, with a regression slope of $5.7 \mathrm{~kg}$ seed per hectare per $\mathrm{mm}$ of irrigation water, representing canola IWUE of $0.57 \mathrm{~kg} / \mathrm{m}^{3}$ water (Figure 7). On average, the highest IWUE was achieved by Sitro $\left(0.67 \mathrm{~kg} / \mathrm{m}^{3}\right)$, followed by Safran $\left(0.64 \mathrm{~kg} / \mathrm{m}^{3}\right)$, while the lowest IWUE was achieved by Sumner $\left(0.43 \mathrm{~kg} / \mathrm{m}^{3}\right)$, whose seed yield was the lowest among the eight varieties (Figure $8 \mathrm{a}$ ). IWUE varied with year, with no correlation between IWUE and the seasonal irrigation amounts. The results of this study are in agreement with Mousavi et al. [60], who reported that the IWUE for winter canola varied from $0.36 \mathrm{~kg} / \mathrm{m}^{3}$ for the least efficient irrigation regime to $0.67 \mathrm{~kg} / \mathrm{m}^{3}$ for the most efficient irrigation regime, under greenhouse conditions. Majnooni-Heris et al. [61] reported spring canola 
IWUE values varying from 0.36 to $0.43 \mathrm{~kg} / \mathrm{m}^{3}$ under different irrigation regimes at the Agriculture and Natural Resources Research Center of Yazd city, Iran. Crop IWUE decreases with increasing irrigation amounts [22,52].

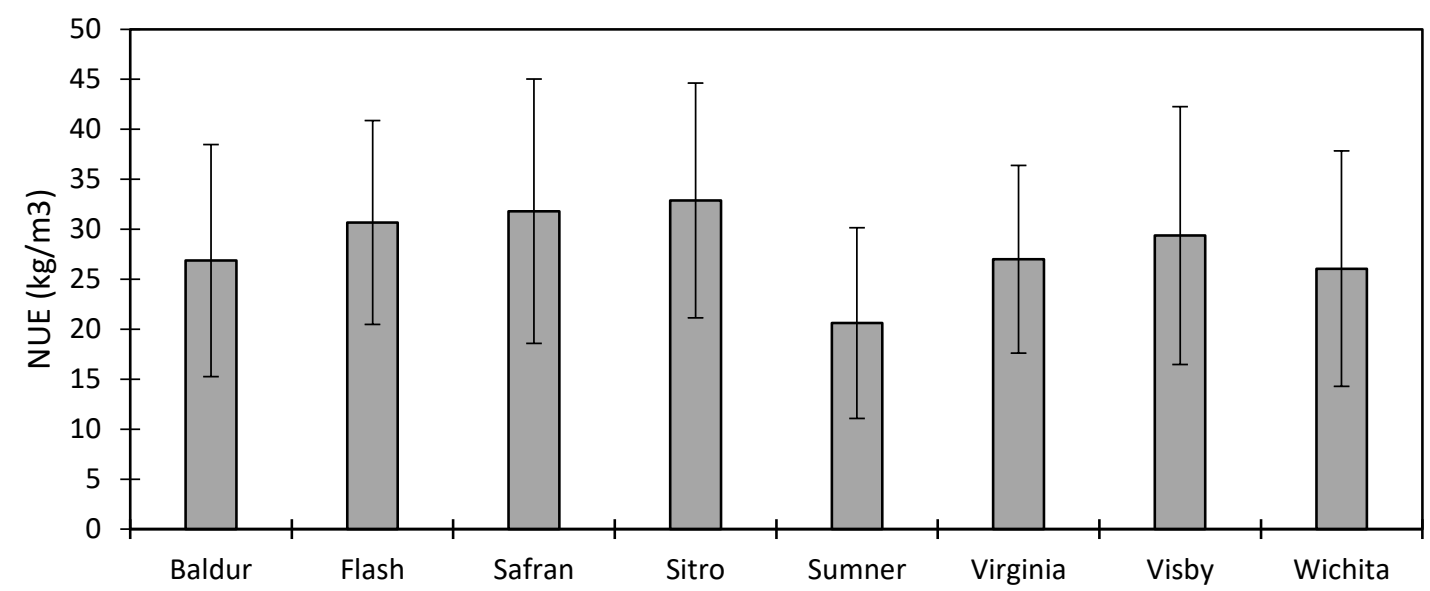

Figure 6. Average and standard deviation of winter canola seed yield.

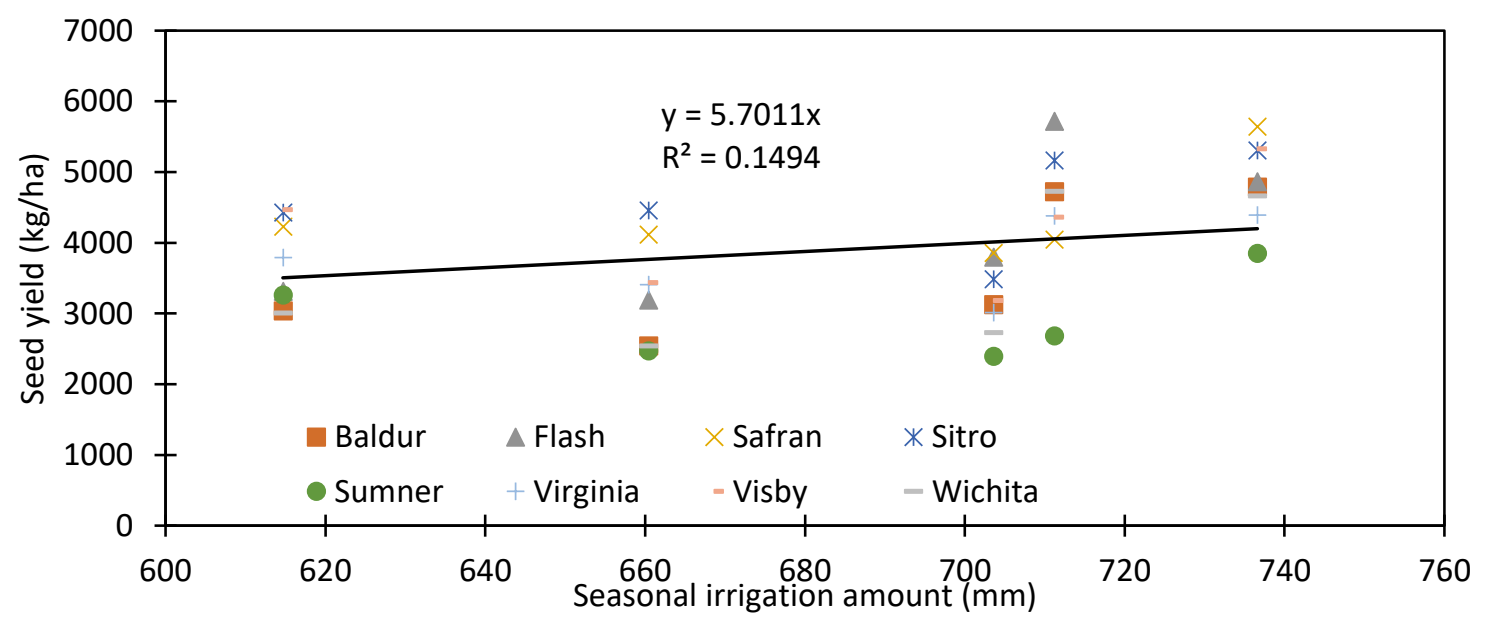

Figure 7. Relationship between winter canola seed yield and seasonal irrigation amount.

Canola CWUE showed inter-annual variability, ranging from 0.28 to $0.69 \mathrm{~kg} / \mathrm{m}^{3}$, and averaging $0.48 \mathrm{~kg} / \mathrm{m}^{3}$ (Table 2). Similar to the IWUE, CWUE was the highest for Sitro and the lowest for Sumner (Figure $8 \mathrm{~b}$ ). Overall, CWUE was at its maximum in the 2011-2012 season, with the greatest amount of total water supply. Canola CWUE varied from 0.27 to $0.86 \mathrm{~kg} / \mathrm{m}^{3}$ in Iran [56] and from 0.03 to $1.8 \mathrm{~kg} / \mathrm{m}^{3}$ in Australia [26,62]. Similar values were reported by Taylor et al. [63]. Takashima et al. [64] reported winter canola WUE varying from 0.16 to $0.67 \mathrm{~kg} / \mathrm{m}^{3}$ in the southeastern Pampas, Argentina. Robertson and Kirkegaard [65] reported higher values of rainfed spring canola WUE, ranging from 0.4 to $1.8 \mathrm{~kg} / \mathrm{m}^{3}$ in southern New South Wales, Australia. Canola CWUE and IWUE values could serve as guidance for water canola production under the semiarid climate of the Four Corners region. 

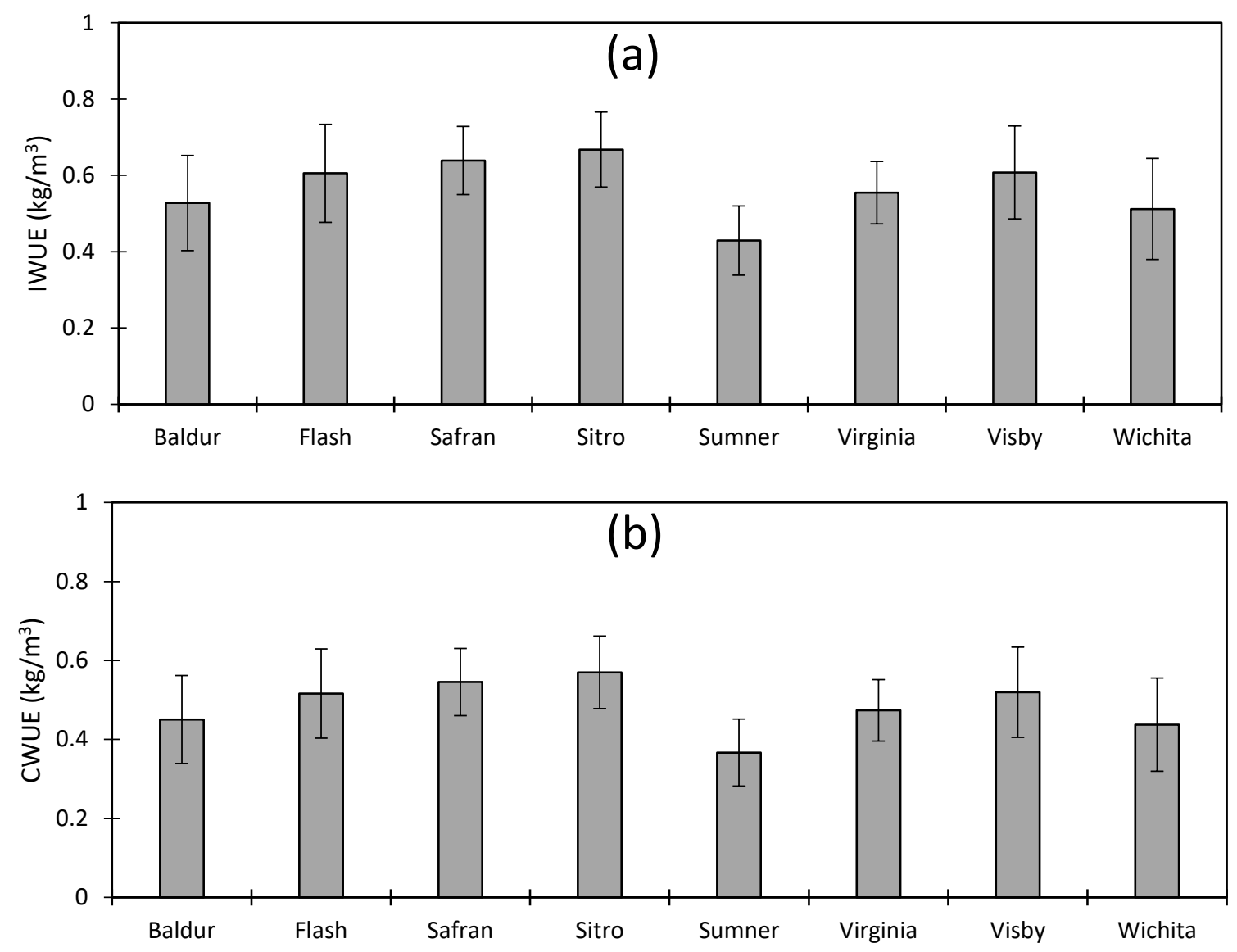

Figure 8. Trends in canola (a) IWUE and (b) CWUE as functions of canola variety (Error bars are standard deviations). IWUE, irrigation water-use efficiency; CWUE, crop water-use efficiency.

\section{Conclusions}

A field experiment was conducted at the New Mexico State Agricultural Science Center at Farmington, to evaluate eight winter canola genotypes for seed yield and water productivity during five growing seasons under sprinkler irrigation. Results showed feasibility of canola production in the Four Corners region, with high winter canola seed yield compared to the Southern High Plains environment. Winter canola seed yield varied from 2393 to $5717 \mathrm{~kg} / \mathrm{ha}$. The highest yield, irrigation, and crop water productivity were achieved by Sitro, and the lowest values of the respective parameters were obtained by Sumner. The high yield achieved at the study site in comparison to many part of the United States offers great promise for canola production in the Four Corners region. The results of this study showed full assessment of canola production under the semiarid climate of the Four Corners region, and could serve as guidelines for winter canola adaptability and incorporation into the crop system, and its profitability for crop producers in the region.

Author Contributions: M.O., C.O., M.W., D.S. and D.B. designed and conducted all field trials with field data collection. K.D., S.V.A., K.K., S.A. and K.L. analyzed the data, wrote and revised the manuscript.

Acknowledgments: The authors would like to extend a special thanks to Curtis Owen and all staff and interns for their outstanding contributions to the work. This study was funded in part by the NMSU Agricultural Experiment Station, the José Fernández Memorial Chair in Crop Production, and the Agriculture and Food Research Initiative (AFRI) of the USDA National Institute of Food and Agriculture (NIFA).

Conflicts of Interest: The authors declare no conflict of interest. 


\section{References}

1. Food and Agriculture Organization of the United Nations (FAO). Statistical Databases; FAO: Rome, Italy, 2018; Available online: http:/ / www.fao.org/statistics/en/ (accessed on 10 April 2018).

2. Organization for Economic Co-operation and Development-Food and Agriculture Organization of the United Nations (OECD-FAO). Agricultural Outlook 2015-2024; OECD Publishing: Paris, France, 2015.

3. Johnston, A.M.; Johnson, E.N.; Kirkland, K.J.; Stevenson, F.C. Nitrogen fertilizer placement for fall and spring seeded Brassica napus canola. Can. J. Plant Sci. 2002, 82, 15-20. [CrossRef]

4. United States Department of Agriculture-Economic Research Service (USDA-ERS). Soybeans and Oil Crops: Canola; U.S. Government Print Office: Washington, DC, USA, 2012.

5. Berrocoso, J.D.; Rojas, O.J.; Liu, Y.; Shoulders, J.; González-Vega, J.C.; Stein, H.H. Energy concentration and amino acid digestibility in high-protein canola meal, conventional canola meal, and soybean meal fed to growing pigs. J. Anim. Sci. 2015, 93, 2208-2217. [CrossRef] [PubMed]

6. Christen, O.; Sieling, K.; Hanus, H. The effect of different preceding crops on the development, growth and yield of wheat. Eur. J. Agron. 1992, 1, 21-28. [CrossRef]

7. Christen, O.; Sieling, K. The effect of different preceding crops on the development, growth and yield of winter barley. J. Agron. Crop Sci. 1993, 171, 114-123. [CrossRef]

8. Norton, R.; Kirkegaardn, J.; Angus, J.; Potter, T. Canola in rotations. In 10th International Rapeseed Congress. Canola in Australia: The First Thirty Years; Salisbury, P., Potter, T., McDonald, G., Green, A., Eds.; The Regional Institute Ltd.: Canberra, Australia, 1999; pp. 23-28.

9. Harker, K.N.; O’Donovan, J.T.; Turkington, T.K.; Blackshaw, R.E.; Lupwayi, N.Z.; Smith, E.G.; Klein-Gebbinck, H.; Dosdall, L.M.; Hall, L.M.; Willenborg, C.J. High-yield no-till canola production on the Canadian prairies. Can. J. Plant Sci. 2012, 92, 221-233. [CrossRef]

10. Khan, S.; Anwar, S.; Kuai, J.; Ullah, S.; Fahad, S.; Zhou, G. Optimization of nitrogen rate and planting density for improving yield, nitrogen use efficiency, and lodging resistance in Oilseed Rape. Front. Plant Sci. 2017, 8, 532. [CrossRef] [PubMed]

11. FAO. Statistical Databases; FAO: Rome, Italy, 2014; Available online: http://www.fao.org/statistics/en/ (accessed on 25 March 2018).

12. USDA. Crop Production 2017 Summary (January 2018); USDA, National Agricultural Statistics Service: Washington, DC, USA, 2018; Volume 128.

13. Kansas State University. National Winter Canola Variety Trial Reports of Progress 1062; Agricultural Experiment Station and Cooperative Extension Service; Kansas State University: Manhattan, NY, USA, 2011.

14. Kansas State University. National Winter Canola Variety Trial Reports of Progress 1080; Agricultural Experiment Station and Cooperative Extension Service; Kansas State University: Manhattan, NY, USA, 2012.

15. Kansas State University. National Winter Canola Variety Trial Reports of Progress 1098; Agricultural Experiment Station and Cooperative Extension Service; Kansas State University: Manhattan, NY, USA, 2013.

16. Kansas State University. National Winter Canola Variety Trial Reports of Progress 1116; Agricultural Experiment Station and Cooperative Extension Service; Kansas State University: Manhattan, NY, USA, 2014.

17. Yang, C.; Gan, Y.; Harker, K.N.; Kutcher, H.R.; Gulden, R.; Irvine, B.; May, W.E. Up to 32\% yield increase with optimized spatial patterns of canola plant establishment in western Canada. Agron. Sustain. Dev. 2014, 34, 793-801. [CrossRef]

18. Gan, Y.K.; Harker, N.; Kutcher, H.R.; Gulden, R.H.; Irvine, B.; May, W.E.; O’Donovan, J.T. Canola seed yield and phenological responses to plant density. Can. J. Plant Sci. 2016, 96, 151-159.

19. Gan, Y.; Malhi, S.S.; Brandt, S.; Katepa-Mupondwa, F.; Stevenson, C. Nitrogen use efficiency and nitrogen uptake of juncea canola diverse environments. Agron. J. 2008, 100, 285-295.

20. Pavlista, A.D.; Santra, D.K.; Isbell, T.A.; Baltensperger, D.D.; Hergert, G.W.; Krall, J.; Mesbach, A.; Johnson, J.; O'Neil, M.; Aiken, R.; et al. Adaptability of irrigated spring canola oil production to the US High Plains. Ind. Crop Prod. 2011, 33, 165-169. [CrossRef]

21. Fisichelli, N.; Vor, T.; Ammer, C. Broadleaf seedling responses to warmer temperatures "chilled" by late frost that favors conifers. Eur. J. For. Res. 2014, 133, 587-596. [CrossRef]

22. Djaman, K.; Irmak, S.; Rathje, W.R.; Martin, D.L.; Eisenhauer, D.E. Maize evapotranspiration, yield production function, biomass, grain yield, harvest index, and yield response factors under full and limited irrigation. Trans. ASABE 2013, 56, 273-293. 
23. Feng, L.; Mathis, G.; Ritchie, G.; Han, Y.; Li, Y.; Wang, G.; Zhi, X.; Bednarz, C.W. Optimizing irrigation and plant density for improved cotton yield and fiber quality. Agron. J. 2014, 106, 1111-1118. [CrossRef]

24. Irmak, S.; Djaman, K.; Rudnick, D.R. Effect of full and limited irrigation amount and frequency on subsurface drip-irrigated maize evapotranspiration, yield, water use efficiency and yield response factors. Irrig. Sci. 2016. [CrossRef]

25. Rudnick, D.; Irmak, S.; Djaman, K.; Sharma, V. Impact of irrigation and nitrogen fertilizer rate on soil water dynamics and maize actual evapotranspiration during the vegetative and reproductive periods. Agric. Water Manag. 2017, 191, 77-84. [CrossRef]

26. Hocking, P.J.; Randall, P.J.; Demarco, D.; Bamforth, I. Assessement of the nitrogen status of field grown canola (Brassica napus L.) by plant analysis. Aust. J. Exp. Agric. 1997, 37, 83-92. [CrossRef]

27. Jackson, G.D. Effects of nitrogen and sulfur on canola yield and nutrient uptake. Agron. J. 2000, 92, 44-49. [CrossRef]

28. Hocking, P.J.; Stapper, M. Effect of sowing time and nitrogen fertilizer on canola and wheat, and nitrogen fertilizer on Indian mustard. I. Dry matter production, grain yield, and yield components. Aust. J. Agric. Res. 2001, 52, 623-634. [CrossRef]

29. Kade, M.; Barneix, A.J.; Olmos, S.; Dubcovsky, J. Nitrogen uptake and remobilization in tetraploid 'Langdon' durum wheat and a recombinant substitution line with the high grain protein gene Gpc-B1. Plant Breed. 2005, 124, 343-349. [CrossRef]

30. Rudnick, D.R.; Irmak, S.; Ferguson, R.B.; Shaver, T.; Djaman, K.; Slater, G.; Bereuter, A.; Ward, N.; Francis, D.; Schmer, M.; et al. Economic return vs crop water productivity of maize for various nitrogen rates under full irrigation, limited irrigation, and rainfed settings in south central Nebraska. J. Irrig. Drain. Eng. ASCE 2016, 142, 1-12. [CrossRef]

31. Ma, B.L.; Biswas, D.K.; Herath, A.W.; Whalen, J.K.; Ruan, S.Q.; Caldwell, C. Growth, yield and yield components of canola as affected by nitrogen, sulphur and boron fertilization. J. Plant Nutr. Soil Sci. 2015, 178, 658-670. [CrossRef]

32. Ma, B.L.; Herath, A.W. Timing and rates of nitrogen fertilizer application on seed yield, quality and nitrogen-use efficiency of canola. Crop Pasture Sci. 2016, 67, 167-180.

33. Nuttall, W.F.; Moulin, A.P.; Smith, L.J.T. Yield response of canola to nitrogen, phosphorus, precipitation, and temperature. Agron. J. 1992, 84, 765-768. [CrossRef]

34. Lamb, K.E.; Johnson, B.L. Seed size and seeding depth influence on canola emergence and performance in the Northern Great Plains. Agron. J. 2004, 96, 454-461. [CrossRef]

35. Assefa, Y.; Prasad, V.; Foster, C.; Wright, Y.; Young, S.; Bradley, P.; Stamm, M.; Ciampitti, I.A. Major management factors determining spring and winter canola yield in North America. Crop Sci. 2018, 58, 1-16. [CrossRef]

36. United States Canola Association (USCA). The United States Canola Association. 2010. Available online: http:/ / www.uscanola.com (accessed on 12 March 2018).

37. Begna, H.S.; Angadi, S. Effects of planting date on winter canola growth and yield in the Southwestern U.S. Am. J. Plant Sci. 2016, 7, 63170. [CrossRef]

38. Begna, S.; Angadi, S.; Stamm, M.; Mesbah, A. Winter Canola: A Potential Dual-Purpose Crop for the United States Southern Great Plains. Agron. J. 2017, 109, 2508-2520. [CrossRef]

39. Boyle, M.C.; Peeper, T.F.; Martin, C.R. Winter Canola Planting Guide for the Southern Great Plains; Publication PSS-2131; Oklahoma Cooperative Extension Service, Oklahoma State University: Stillwater, OK, USA, 2004; Available online: http:/ / pods.dasnr.okstate.edu (accessed on 29 March 2018).

40. Russo, V.M.; Bruton, B.D.; Sams, C.E. Classification of temperature response in germination of brassicas. Ind. Crops Prod. 2010, 31, 48-51. [CrossRef]

41. Neely, C.; Trostle, C.; Bell, J.; McGinty, J.; Hathcoat, D.; Kimura, E.; McLellan, S.; DeLaune, P.; Mike Stamm, M.; Dooley, S. Texas Uniform Canola Variety Trials; SCS-2016-24; Texas A\&M AgriLife Extension: College Station, TX, USA, 2016.

42. Baylis, A.D.; Wright, I.T.J. The effects of lodging and a paclobutrazol—Chlormequat chloride mixture on the yield and quality of oilseed rape. Ann. Appl. Biol. 1990, 116, 287-295. [CrossRef]

43. Berry, P.M.; Spink, J.H. Understanding the effect of a triazole with anti-gibberellin activity on the growth and yield of oilseed rape (Brassica napus). J. Agric. Sci. 2009, 147, 273-285. [CrossRef] 
44. Khan, S.; Anwar, S.; Kuai, J.; Noman, A.; Shahid, M.; Din, M.; Ali, A.; Zhou, G. Alteration in yield and oil quality traits of winter rapeseed by lodging at different planting density and nitrogen rates. Sci. Rep. 2018. [CrossRef] [PubMed]

45. Djaman, K.; O’Neill, M.; Owen, C.; Smeal, D.; West, M.; Begay, D.; Allen, S.; Koudahe, K.; Irmak, S.; Lombard, K. Long-term winter wheat seasonal irrigation amount, evapotranspiration, yield, and water productivity under semiarid climate. Agronomy 2018. submitted.

46. Trostle, C.; Bean, B.; Nansen, C.; Baltensperger, D.; Smith, J.; Todd Baughman, T.; Angadi, S.; O’Neill, M.; Flynn, R.; Libbin, J.; et al. Canola Adaptation and Production in the Southern High Plains; Texas AgriLife Extension Service \& New Mexico State University: Las Cruces, NM, USA, 2009.

47. Kirkland, K.J.; Johnson, E.N. Alternative seeding dates (fall and April) affect Brassica napus canola yield and quality. Can. J. Plant Sci. 2000, 80, 713-719. [CrossRef]

48. Canola Council of Canada. Temperature, Frost and Hail; Canola Council of Canada: Winnipeg, MB, Canada, 2005; Available online: http:/ / www.canola-council.org/chapter5.aspx\#ch5_sec1a (accessed on 13 January 2010).

49. Hergert, G.W.; Margheim, G.F.; Pavlista, A.D.; Martin, D.L.; Supalla, R.J.; Isbell, T.A. Yield, irrigation response, and water productivity of deficit to fully irrigated spring canola. Agric. Water Manag. 2016, 168, 96-103. [CrossRef]

50. Assefa, Y.; Roozeboom, K.; Stamm, M. Winter canola yield and survival as a function of environment, genetics, and management. Crop Sci. 2014, 54, 2303-2313. [CrossRef]

51. Stamm, M.; La Barge, C.; Berrada, A.; Bhardwaj, H.; Caldbeck, B.; Casteel, S. National Winter Canola Variety Trial; SRP1026; Agricultural Experiment Station and Cooperative Extension Service; Kansas State University: Manhattan, KS, USA, 2010.

52. Sharma, H.; Shukla, M.K.; Bosland, P.W.; Steiner, R.L. Physiological responses of greenhouse-grown drip-irrigated Chile pepper under partial root zone drying. HortScience 2015, 50, 1224-1229.

53. Martinez-Feria, R.A.; Kaspar, T.C.; Wiedenhoeft, M.H. Seeding Date Affects Fall Growth of Winter Canola (Brassica napus L. 'Baldur') and its Performance as a Winter Cover Crop in Central Iowa. Crop Forage Turfgrass Manag. 2016, 2. [CrossRef]

54. Chamorro, A.M.; Tamagno, L.N.; Bezus, R.; Sarandón, S.J. Nitrogen accumulation, partition, and nitrogen-use efficiency in canola under different nitrogen availabilities. Commun. Soil Sci. Plant Anal. 2002, 33, 493-504. [CrossRef]

55. Sieling, K.; Kage, H. Efficient N management using winter oilseed rape. A review. Agron. Sustain. Dev. 2010, 30, 271-279. [CrossRef]

56. Koocheki, A.; Nassiri Mahallati, M.; Moradi, R.; Mansoori, H. Optimizing water, nitrogen and crop density in canola cultivation using response surface methodology and central composite design. Soil Sci. Plant Nutr. 2014, 60, 286-298. [CrossRef]

57. Rathke, G.W.; Behrens, T.; Diepenbrock, W. Integrated nitrogen management strategies to improve seed yield, oil content and nitrogen efficiency of winter oilseed rape (Brassica napus L.): A review. Agric. Ecosyst. Environ. 2006, 117, 80-108. [CrossRef]

58. Svecnjak, Z.; Rengel, Z. Nitrogen utilization efficiency in canola cultivars at grain harvest. Plant Soil 2006, 283, 299-307. [CrossRef]

59. Bouchet, A.S.; Laperche, A.; Bissuel-Belaygue, C.; Snowdon, R.; Nesi, N.; Stahl, A. Nitrogen use efficiency in rapeseed. A review. Agron. Sustain. Dev. 2016, 36, 1-20. [CrossRef]

60. Mousavi, S.F.; Soltani-Gerdefaramarzi, S.; Mostafazadeh-Fard, B. Effects of partial rootzone drying on yield, yield components, and irrigation water use efficiency of canola (Brassica napus L.). Paddy Water Environ. 2010, 8, 157-163. [CrossRef]

61. Majnooni-Heris, A.; Nazemi, A.H.; Sadraddini, A.A. Effects of deficit irrigation on the yield, yield components, water and irrigation water use efficiency of spring canola. J. Biodivers. Environ. Sci. 2014, 5, 44-53.

62. Cocks, B.; Robertson, M.J.; Cawley, S. Water extraction and water use efficiency of canola in the north. In Proceedings of the Australian Research Assembly on Brassicas, Geelong, Australia, 2-5 October 2001.

63. Taylor, A.J.; Smith, C.J.; Wilson, I.B. Effect of irrigation and fertiliser on yield, oil content, nitrogen accumulation and water use of canola (Brassica napus L.). Fertil. Res. 1991, 29, 249-260. [CrossRef] 
64. Takashima, N.E.; Rondanini, D.P.; Puhl, L.E.; Miralles, D.J. Environmental factors affecting yield variability in spring and winter rapeseed genotypes cultivated in the southeastern Argentine Pampas. Eur. J. Agron. 2013, 48, 88-100. [CrossRef]

65. Robertson, M.J.; Kirkegaard, J.A. Water-use efficiency of dryland canola. Aust. J. Agric. Res. 2005, 56, 1373-1386. [CrossRef] 